Chapman University

Chapman University Digital Commons

Mathematics, Physics, and Computer Science

Science and Technology Faculty Articles and

Faculty Articles and Research

Research

4-7-2017

\title{
Thujone inhibits the function of a7-nicotinic acetylcholine receptors and impairs nicotine- induced memory enhancement in one-trial passive avoidance paradigm
}

Ahmed Sultan

UAE University

Keun-Hang Susan Yang

ChapmanUniversity, kyang@chapman.edu

Dmytro Isaev

UAE University, Al Ain, Abu Dhabi, UAE

Eslam El Nebrisi

UAE University

Nurulain Syed

UAE University

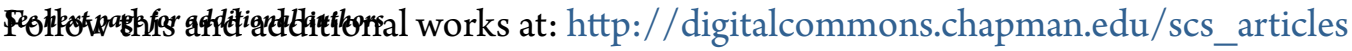

Part of the Animals Commons, Cell Biology Commons, Medical Neurobiology Commons, and the Substance Abuse and Addiction Commons

\section{Recommended Citation}

Sultan, Ahmed, Yang, Keun-Hang Susan, Isaev, Dmitro, Nebrisi, Eslam El, Syed, Nurulain, Khan, Nadia, Howarth, Christopher F., Sadek, Bassem, Oz, Murat. (2017). Thujone inhibits the function of $\alpha 7$-nicotinic acetylcholine receptors and impairs nicotine-induced memory enhancement in one-trial passive avoidance paradigm. Toxicology. http://dx.doi.org/10.1016/j.tox.2017.04.005

This Article is brought to you for free and open access by the Science and Technology Faculty Articles and Research at Chapman University Digital Commons. It has been accepted for inclusion in Mathematics, Physics, and Computer Science Faculty Articles and Research by an authorized administrator of Chapman University Digital Commons. For more information, please contact laughtin@chapman.edu. 


\section{Thujone inhibits the function of a 7-nicotinic acetylcholine receptors and impairs nicotine-induced memory enhancement in one-trial passive avoidance paradigm}

\section{Comments}

NOTICE: this is the author's version of a work that was accepted for publication in Toxicology. Changes resulting from the publishing process, such as peer review, editing, corrections, structural formatting, and other quality control mechanisms may not be reflected in this document. Changes may have been made to this work since it was submitted for publication. A definitive version will be subsequently published in Toxicology in 2017. DOI: $10.1016 /$ j.tox.2017.04.005

The Creative Commons license below applies only to this version of the article.

\section{Creative Commons License} (c) $($ ) $(9)$

This work is licensed under a Creative Commons Attribution-Noncommercial-No Derivative Works 4.0 License.

\section{Copyright}

Elsevier

\section{Authors}

Ahmed Sultan, Keun-Hang Susan Yang, Dmytro Isaev, Eslam El Nebrisi, Nurulain Syed, Nadia Khan, Christopher F. Howarth, Bassem Sadek, and Murat Oz 


\section{Accepted Manuscript}

Title: Thujone inhibits the function of $\alpha_{7}$-nicotinic acetylcholine receptors and impairs nicotine-induced memory enhancement in one-trial passive avoidance paradigm $<$ ! $-<$ RunningTitle $>$ Effects of thujone on $\alpha_{7}$-nACh receptors $<$ /RunningTitle $>->$

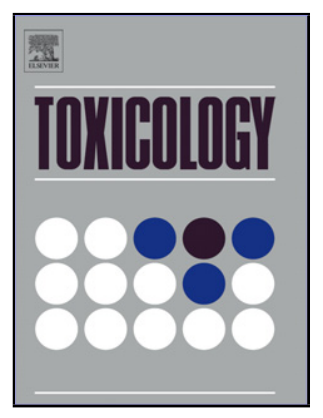

Authors: Ahmed Sultan, Keun-Hang Susan Yang, Dmitro Isaev, Eslam El Nebrisi, Nurulain Syed, Nadia Khan, Christopher F. Howarth, Bassem Sadek, Murat Oz

PII: S0300-483X(17)30103-8

DOI: http://dx.doi.org/doi:10.1016/j.tox.2017.04.005

Reference: TOX 51863

To appear in: Toxicology

Received date: $\quad$ 7-3-2017

Revised date: $\quad$ 4-4-2017

Accepted date: $\quad$ 6-4-2017

Please cite this article as: Sultan, Ahmed, Yang, Keun-Hang Susan, Isaev, Dmitro, Nebrisi, Eslam El, Syed, Nurulain, Khan, Nadia, Howarth, Christopher F., Sadek, Bassem, Oz, Murat, Thujone inhibits the function of $\alpha 7$-nicotinic acetylcholine receptors and impairs nicotine-induced memory enhancement in one-trial passive avoidance paradigm.Toxicology http://dx.doi.org/10.1016/j.tox.2017.04.005

This is a PDF file of an unedited manuscript that has been accepted for publication. As a service to our customers we are providing this early version of the manuscript. The manuscript will undergo copyediting, typesetting, and review of the resulting proof before it is published in its final form. Please note that during the production process errors may be discovered which could affect the content, and all legal disclaimers that apply to the journal pertain. 
Thujone inhibits the function of $\alpha_{7}$-nicotinic acetylcholine receptors and impairs nicotine-induced memory enhancement in one-trial passive avoidance paradigm

${ }^{1}$ Ahmed Sultan, ${ }^{2}$ Keun-Hang Susan Yang, ${ }^{1}$ Dmitro Isaev, ${ }^{1}$ Eslam El Nebrisi, ${ }^{1}$ Nurulain Syed, ${ }^{1}$ Nadia Khan, ${ }^{3}$ Christopher F. Howarth, ${ }^{1}$ Bassem Sadek,,${ }^{1,4}$ Murat Oz

Departments of ${ }^{1}$ Pharmacology and ${ }^{3}$ Physiology, College of Medicine and Health Sciences, UAE University, Al Ain, UAE, ${ }^{2}$ Department of Biological Sciences, Schmid College of Science and Technology, Chapman University, One University Drive, Orange, CA 92866, USA, ${ }^{4}$ Department of Basic Medical Sciences, College of Medicine, Qatar University, Doha, Qatar

Running title: Effects of thujone on $\alpha_{7}$-nACh receptors

\section{Corresponding author:}

Murat Oz, M.D., Ph.D.

Department of Pharmacology, Laboratory of Functional Lipidomics

Faculty of Medicine and Health Sciences, UAEU

Abu Dhabi, Al Ain, UAE

Phone: (971)-03-713-7523;

Fax: (971)-03-767-2033;

E-mail: Murat_Oz@uaeu.ac.ae

Abbreviations: ACh, Acetylcholine; ANOVA, analysis of variance; BAPTA, 1,2-bis (o-aminophenoxy) ethane- $N, \quad N, \quad N^{\prime}, \quad N^{\prime}$-tetraacetic acid; HEPES, 4-(2-hydroxyethyl) piperazineethane sulfonic acid; MLA, methyllycaconitine; MBS, modified Barth's solution. 


\begin{abstract}
Effects of thujone, a major ingredient of absinthe, wormwood oil and some herbal medicines, were tested on the function of $\alpha_{7}$ subunit of the human nicotinic acetylcholine $\left(\alpha_{7} \mathrm{nACh}\right)$ receptor expressed in Xenopus oocytes using the two-electrode voltage-clamp technique. Thujone reversibly inhibited ACh $(100 \mu \mathrm{M})$-induced currents with an $\mathrm{IC}_{50}$ value of $24.7 \mu \mathrm{M}$. The effect of thujone was not dependent on the membrane potential and did not involve $\mathrm{Ca}^{2+}$-dependent $\mathrm{Cl}^{-}$ channels expressed endogenously in oocytes. Inhibition by thujone was not reversed by increasing ACh concentrations. Moreover, specific binding of $\left[{ }^{125} \mathrm{I}\right] \alpha$-bungarotoxin was not altered by thujone. Further experiments in SH-EP1 cells expressing human $\alpha_{7} \mathrm{nACh}$ receptor indicated that thujone suppressed choline induced $\mathrm{Ca}^{2+}$ transients in a concentration-dependent manner. In rat hippocampal CA3-dentate gyrus synapses, nicotine-induced enhancement of long-term potentiation was also inhibited by thujone. Furthermore, the results observed in in-vivo one-trial passive avoidance paradigm show that thujone (1.25 $\mathrm{mg} / \mathrm{kg}$, i.p.) significantly impaired nicotine-induced enhancement of learning and memory in Wistar rats. Collectively, our results indicate that thujone inhibits the function of the $\alpha 7-\mathrm{nACh}$ receptor and impairs cellular and behavioral correlates of cholinergic modulation of learning and memory.
\end{abstract}

Keywords: Nicotinic receptors; thujone; absinthe; Xenopus oocyte, passive avoidance paradigm, memory. 


\section{Introduction}

Absinthe is an alcoholic beverage popular in the late $19^{\text {th }}$ century in Europa and later in USA. Consumption of absinthe has been linked to a psychoactive syndrome (absinthism) characterized by hallucinations, cognitive impairments and seizures (Dettling,et al., 2004; Gambelunghe and Melai, 2002; Holstege et al., 2002; Olsen, 2000; Pelkonen et al., 2013). Absinthism has been suggested to correlate with the presence of wormwood (Artemisia absinthium L.) in the absinthe (Gambelunghe and Melai, 2002; Olsen, 2000; Pelkonen et al., 2013). Although recently differing views have been expressed (Padosch et al., 2006), the monoterpene thujone generally is considered to be the principal active ingredient of wormwood oil and be responsible for toxic properties of absinthe (Gambelunghe and Melai, 2002; Holstege et al., 2002; Olsen, 2000; Pelkonen et al., 2013).

Although the neurotoxic effects of thujone in mammals have been reported in earlier studies (Dettling et al., 2004; Olsen, 2000; Gambelunghe and Melai, 2002; Holstege et al., 2002; Lachenmeier, 2010; Pelkonen et al., 2013), the mechanisms of these toxic actions are poorly understood. In earlier studies the effects of thujone on the functions of ligand-gated ion channels such as GABA $_{\mathrm{A}}$ (Czyzewska and Mozrzymas, 2013; Hall et al., 2004; Hold et al., 2000; Rivera et al., 2014; Sánchez-Borzone et al., 2014; Szczot et al., 2012), and 5-HT 3 (Deiml et al., 2004) receptors have been reported. In fact, it is widely accepted that the convulsant and anxiogenic effects of absinthe are linked to inhibition of $\mathrm{GABA}_{\mathrm{A}}$ receptors by thujone (Hold et al., 2000; Rivera et al., 2014; Sánchez-Borzone et al., 2014; Szczot et al., 2012).

Nicotinic acetylcholine (nACh) receptors are important members of the ligand-gated ion channel family that includes $\mathrm{GABA}_{\mathrm{A}}$ and $5-\mathrm{HT}_{3}$ receptors. Nicotinic receptors are divided into two 
groups; muscle nicotinic receptors, which are found at the skeletal muscle junction where they mediate neuromuscular transmission and neuronal nicotinic receptors which are found throughout the peripheral and central nervous systems where they are involved in fast synaptic transmission and in the modulation of transmitter release (for reviews; (Albuquerque et al., 2009; Hogg et al., 2003). Importantly, $\alpha_{7}$-nACh receptors, which have considerably high permeability to $\mathrm{Ca}^{2+}$, have been shown to be located on both glutamatergic and GABAergic nerve terminals suggesting that excitatory and inhibitory synaptic transmission can be modulated by the activity of these receptors (Albuquerque et al., 2009; Hogg et al., 2003). Notably, $\alpha_{7}$-nACh receptors are widely distributed throughout the central nervous system, mainly the cortical, thalamic and hippocampal regions that are closely linked to memory and learning (Albuquerque et al., 2009). In the present study, we have investigated the effects of thujone on human $\alpha_{7}$-nACh receptors expressed in Xenopus oocytes and SH-EP1 cells, and tested its effects on cellular and behavioral correlates of learning and memory by using hippocampal brain slices and one-trial passive avoidance paradigm in adult male Wistar rats. Specifically, we provide evidence indicating that thujone inhibits the functions of rat and human $\alpha_{7}$-nACh receptors. 


\section{Materials and Methods}

2.1. Recordings from oocytes: Mature female Xenopus laevis frogs were purchased from Xenopus Express (Haute-Loire, France) and housed in dechlorinated tap water at $19-21{ }^{\circ} \mathrm{C}$ with a 12/12-hour light/dark cycle and fed with food pellets supplied by Xenopus Express. The procedures followed in this study were in accordance with the Guide for the Care and Use of Laboratory Animals of the National Institutes of Health (Bethesda, MD) and approved by the Institutional Animal Care and Use Committee at the College of Medicine and Health Sciences, UAEU. Clusters of oocytes were removed surgically under benzocaine (Sigma, St. Louis, MO) local anesthesia $(0.03 \% \mathrm{w} / \mathrm{V})$ and individual oocytes were dissected away manually in a solution containing (in $\mathrm{mM}$ ): $\mathrm{NaCl}, 88 ; \mathrm{KCl}, 1 ; \mathrm{NaHCO}_{3}, 2.4 ; \mathrm{MgSO}_{4}, 0.8$; HEPES, 10 (pH 7.5) as described earlier (Brauneis et al., 1996; Oz et al., 2004a). Dissected oocytes were then stored for two to seven days in modified Barth's solution (MBS) containing (in $\mathrm{mM}$ ): $\mathrm{NaCl}, 88 ; \mathrm{KCl}, 1$; $\mathrm{NaHCO}_{3}, 2.4 ; \mathrm{CaCl}_{2}, 2 ; \mathrm{MgSO}_{4}, 0.8 ; \mathrm{HEPES}, 10(\mathrm{pH}$ 7.5), supplemented with $2 \mathrm{mM}$, sodium pyruvate, $10,000 \mathrm{IU} / \mathrm{L}$ penicillin, $10 \mathrm{mg} / \mathrm{L}$ streptomycin, $50 \mathrm{mg} / \mathrm{L}$ gentamicin, , and $0.5 \mathrm{mM}$ theophylline. Briefly, oocytes were placed in a $0.2 \mathrm{ml}$ recording chamber and superfused at a rate of 3-4 $\mathrm{ml} / \mathrm{min}$. Under these conditions, solution exchange time was less than $100 \mathrm{msec}$. The bathing solution contained (in $\mathrm{mM}$ ): $\mathrm{NaCl}, 96 ; \mathrm{KCl}, 2 ; \mathrm{CaCl}_{2}, 1.8 ; \mathrm{MgCl}_{2}, 1$ and $\mathrm{HEPES} 5$ (pH 7.5). The cells were impaled with two glass microelectrodes filled with a $3 \mathrm{M} \mathrm{KCl}(0.5-2 \mathrm{M} \Omega)$. The oocytes were routinely voltage clamped at a holding potential of $-70 \mathrm{mV}$ using a GeneClamp-500 amplifier (Axon Instruments Inc., Burlingame, CA) and current responses were recorded and stored digitally for further analysis.

Drugs were applied by gravity flow via a micropipette positioned about $2 \mathrm{~mm}$ from the 
oocyte. Some of the compounds were applied externally by addition to the superfusate (flow rate of $3-4 \mathrm{ml} / \mathrm{min}$ ). Acetylcholine, thujone, methyllycaconitine (MLA), $\alpha$-bungarotoxin and all chemicals used were obtained from Sigma (St. Louis, MO). Procedures for the injections of BAPTA (50-100 nl, $100 \mathrm{mM}$ ) were performed as described previously (Oz et al., 1998). Stock solutions of thujone used in this study were prepared in ethanol at a concentration of $100 \mathrm{mM}$. At the highest final concentrations used $(0.1 \% \mathrm{v} / \mathrm{v})$, ethanol did not have a significant effect on ACh $(100 \mu \mathrm{M})$-induced currents $(\mathrm{n}=6)$.

The cDNA clone of human $\alpha_{7}$-nACh receptor was kindly provided by Dr. J. Lindstrom (University of Pennsylvania, PA). Capped cRNA transcripts were synthesized in vitro using a mMESSAGE mMACHINE kit from Ambion (Austin, TX) and analyzed on $1.2 \%$ formaldehyde agarose gel to check the size and the quality of the transcripts. Approximately 3-5 ng of cRNA was injected into each oocyte. The cDNAs for human $\alpha 4, \beta 2, \alpha 3$, and $\beta 4$ subunits were kindly provided by Dr. Isabel Bermudez. Subunit combinations, $\alpha$ and $\beta$ subunits were injected at 1:1 ratio.

2.2. Radioligand binding studies: Oocytes were injected with 5 ng human $\alpha_{7}$-nACh receptor cRNA, and the functional expression of the receptors was tested by electrophysiology on day three. Isolation of oocyte membranes was carried out by modification of a method described earlier $(\mathrm{Oz}$ et al., 2004b; Mahgoub et al.,2013). Briefly, oocytes (200-300 oocytes per assay) were suspended (approximately $20 \mu \mathrm{l} /$ oocyte) in a homogenization buffer containing (in mM) HEPES 10, EDTA 1, PMSF 0.1, and $0.02 \% \mathrm{NaN}_{3}, 50 \mu \mathrm{g} / \mathrm{mL}$ bacitracin ( $\mathrm{pH} 7.4$ ) at $4{ }^{\circ} \mathrm{C}$ on ice and homogenized using a motorized Teflon homogenizer (six strokes, $15 \mathrm{sec}$ each at high speed). The homogenate was centrifuged for $10 \mathrm{~min}$ at $800 \mathrm{~g}$. The supernatant was collected and the pellet was resuspended 
in homogenization buffer and recentrifuged at $800 \mathrm{~g}$ for $10 \mathrm{~min}$. Supernatants were then combined and centrifuged for 1 hour at $36,000 \mathrm{~g}$. The membrane pellet was resuspended in homogenization buffer and used for the binding studies.

Binding assays were performed in $500 \mu \mathrm{L}$ of $10 \mathrm{mM}$ HEPES (pH 7.4) containing $50 \mu \mathrm{L}$ of oocyte preparation and $0.1-5 \mathrm{nM}\left[{ }^{125} \mathrm{I}\right] \alpha$-bungarotoxin $(2200 \mathrm{Ci} / \mathrm{mmol}$; Perkin-Elmer, Inc. Waltham, MA). Nonspecific binding was determined using $10 \mu \mathrm{M} \alpha$-bungarotoxin. Oocyte membranes were incubated with $\left[{ }^{125} \mathrm{I}\right] \alpha$-bungarotoxin in the absence and presence of drugs, for 1 $\mathrm{h}$ at room temperature $\left(22-24{ }^{\circ} \mathrm{C}\right)$. The radioligand was separated by rapid filtration onto $\mathrm{GF} / \mathrm{C}$ filters presoaked in $0.2 \%$ polyethyleneimine. Filters were then washed with two $5 \mathrm{ml}$ washes of ice-cold HEPES buffer, and the radioactivity was determined by counting samples in a Beckman Gamma-300 $\gamma$-counter.

2.3. SH-EP1 cell culture: The SH-EP1 cells stably expressing the human $\alpha 7 \mathrm{nAChR}$, were a gift from Dr. R Lukas (Barrow Neurological Institute, Phoenix, AZ). Culturing of SH-EP1 cells was described earlier (Spivak et al., 2007). Briefly, cells were grown on 35-mm dishes in Dulbecco's modified Eagle's medium (Invitrogen, Carlsbad, CA, USA) supplemented with 10\% heat inactivated horse serum, $5 \%$ fetal bovine serum, $1 \mathrm{mM}$ sodium pyruvate, $100 \mathrm{U} / \mathrm{ml}$ penicillin $\mathrm{G}$, $100 \mu \mathrm{g} / \mathrm{ml}$ streptomycin, $0.25 \mu \mathrm{g} / \mathrm{ml}$ amphotericin $\mathrm{B}, 0.4 \mathrm{mg} / \mathrm{ml}$ hygromycin $\mathrm{B}$, and $0.25 \mathrm{mg} / \mathrm{ml}$ Zeocin (all from Invitrogen). For measurements of intracellular $\left[\mathrm{Ca}^{2+}\right]$, cells were plated at a density of $2 \times 10^{5}$ cells per well into 96 -well plates and were kept for $2-3$ days at $37{ }^{\circ} \mathrm{C}$ in an atmosphere of 5\% $\mathrm{CO}_{2}$ saturated with $\mathrm{H}_{2} \mathrm{O}$. Experiments were performed at room temperature (24 $\left.\pm 2{ }^{\circ} \mathrm{C}\right)$. 
2.4. Measurement of intracellular $\left[\mathbf{C a}^{2+}\right]$ : The SH-EP1 cells were loaded with Krebs-HEPES (in mM: $144 \mathrm{NaCl}, 5.9 \mathrm{KCl}, 1.2 \mathrm{MgCl}_{2}, 2 \mathrm{CaCl}_{2}, 11$ D-glucose, 10 HEPES, pH 7.4) containing $10 \mu \mathrm{M}$ fluo-4 AM (Molecular Probes, Life Technologies, Paisley, UK) for 45 min at $37{ }^{\circ} \mathrm{C}$ in the dark. After this incubation period, cells were washed twice with Krebs-HEPES at room temperature in the dark. Atropine $(1 \mu \mathrm{M})$ was included in all test and incubation solutions. Changes in fluorescence (excitation $485 \mathrm{~nm}$, emission $520 \mathrm{~nm}$ ) were measured using a fluorescent plate reader (Fluostar, BMG Labtech Inc., Cary, NC, USA). Basal levels of fluorescence were monitored before adding stimulation solution $(200 \mu \mathrm{M} \mathrm{ACh})$ by using an automatic dispenser. After stimulation, changes in fluorescence were measured for $30 \mathrm{sec}$. To normalize fluo-4 signals, responses from each well were calibrated by measuring maximum and minimum fluorescence values. At the end of each experiment, addition of $75 \mu 1$ of $5 \%$ Triton $X-100\left(F_{\max }\right)$ was followed by addition of $50 \mu \mathrm{l}$ of $1 \mathrm{M} \mathrm{MnCl}_{2}\left(\mathrm{~F}_{\min }\right)$. Data were calculated as a percentage of $\mathrm{F}_{\max }-\mathrm{F}_{\min }$ and presented as $\%$ of $\mathrm{F}_{\max }-\mathrm{F}_{\min }$ or area under fluorescence curve (AUC).

2.6. Extracellular recordings of field potentials in rat hippocampal slices: Male Wistar rats (15-30 days old) were killed by $\mathrm{CO}_{2}$ narcosis followed by decapitation. Their brains were removed in ice cold artificial cerebrospinal fluid (ACSF), which was composed of (in $\mathrm{mM}$ ): $\mathrm{NaCl}, 125$; $\mathrm{NaHCO}_{3}, 25 ; \mathrm{KCl}, 2.5 ; \mathrm{NaH}_{2} \mathrm{PO}_{4}, 1.25 ; \mathrm{CaCl}_{2}, 2, \mathrm{MgCl}_{2}, 1$; and glucose, 25. Transverse slices of 350-400 $\mu \mathrm{m}$ thickness were cut using a Vibratome and stored at room temperature in an immersion chamber containing ACSF bubbled with $95 \% \mathrm{O}_{2}$ and $5 \% \mathrm{CO}_{2}$ for 1 hour. Standard electrophysiological techniques were used to record field potentials as described earlier (Hoffman et al., 2007; Singhal et al., 2007). Briefly, transverse slices of hippocampus were transferred to the recording chamber and continuously superfused with $4 \mathrm{~mL} / \mathrm{min}$ ACSF solution at $30-32{ }^{\circ} \mathrm{C}$. All 
solutions contained $100 \mu \mathrm{M}$ bicuculline to block $\mathrm{GABA}_{\mathrm{A}}$ receptors. Perfusion of thujone was started 5 min prior to high-frequency stimulation (HFS) apart from nicotine which was perfused for 10 min prior to HFS.

Presynaptic stimulation was applied to the medial perforant pathway of the dentate gyrus using a bipolar insulated tungsten wire electrode, and field excitatory postsynaptic potentials (fEPSPs) were recorded at a control test frequency of $0.033 \mathrm{~Hz}$ (every $20 \mathrm{sec}$ ) from the middle one-third of the molecular layer of the dentate gyrus with a glass microelectrode filled with extracellular solution. The inner blade of the dentate gyrus was used in all studies. In each experiment, an input-output curve (afferent stimulus intensity versus fEPSP amplitude) was plotted at the test frequency. In each experiment, an input-output curve (stimulus intensity vs. fEPSP amplitude) was plotted at the test frequency. For all experiments, the amplitude of the test fEPSP was adjusted to one-third of maximum (approximately $1.5 \mathrm{mV}$ ). LTP was evoked by high frequency stimulation (HFS) consisting of 8 trains, each of 8 stimuli at $200 \mathrm{~Hz}$, intertrain interval $2 \mathrm{~s}$, with the stimulation voltage increased during the HFS so as to elicit an initial fEPSP of the train of double the normal test EPSP amplitude. Measurements of LTP were recorded for 60 min after HFS. Recordings were analysed using p-CLAMP 8.1 (Axon Instruments, CA, USA). Values are the means \pm SEM for $n$ slices.

2.8. In-vivo pharmacology: Male Wistar rats aged $8-10$ weeks (bred at the Central Animal Facility of the UAE University) and at a body weight of 180-200 g were used. The animals were paired randomly and housed in pairs in an air-conditioned room with controlled temperature (24 $\pm 1^{\circ} \mathrm{C}$ ) and humidity $(55 \pm 15 \%)$ under a 12 -h light/dark cycle (lights on at 07:00 h). The animals were given free access to food and water. Experiments were conducted between 9:00 and 15:00 h, 
and all procedures were performed in accordance with the guidelines of the European Communities Council Directive of 2010 (2010/63/EU) and were approved by the Institutional Animal Ethics Committee of the College of Medicine and Health Sciences/United Arab Emirates University (ERA-2015-3132). Naïve rats were handled for a week before drug treatment began. Thujone, nicotine, and methyllycaconitine (MLA) were purchased from Sigma (St.Louis, MO, USA). They were dissolved in isotonic saline and administered intraperitoneally (i.p.) at a volume of $1 \mathrm{ml} / \mathrm{kg}$. All doses were expressed in terms of the free base. All experiments were conducted in a blinded fashion in which the operator was unaware of the specific treatment groups to which an animal belonged.

2.8.3. One-trial step-through passive avoidance test: The step-through passive avoidance is a paradigm to evaluate long term memory in experimental animals. The passive avoidance test was conducted in an automatically operated commercial Passive Avoidance Apparatus as previously described (Step-through Cage, 7550, Ugo Basile, Comerio, Italy) (Bernaerts et al., 2004; da Silva et al., 2009; Khan et al., 2015; Sadek et al., 2016a; 2016b). The apparatus consists of two equal size compartments $(51 \times 25 \times 24 \mathrm{~cm}$ each) with grid floors which can be electrified separately. The walls of the first compartment are painted white, and the second compartment is dark with its walls painted black. A guillotine door connects the two compartments. The experiment consisted of two trials (training and testing) separated by a $24 \mathrm{~h}$ interval. Accordingly, each rat in the first trial was placed in the white compartment, facing the guillotine door and, after a 30-s habituation period, the door was raised automatically. A $60 \mathrm{~s}$ cut-off time was given for the animal to cross to the dark compartment. Animals that did not move within this period were excluded from the test on the second day. As soon as the rat placed all four paws in the dark compartment, the guillotine door 
was lowered and a scrambled foot shock of $0.4 \mathrm{~mA}(20 \mathrm{~Hz}, 8.3 \mathrm{~ms})$ was delivered to the grid floor for $3 \mathrm{~s}$. The intensity of the shock was selected after establishing the sensitivity threshold that produces minimum vocalization and jumping responses. Immediately after receiving the shock, the rat was removed from the dark chamber, returned to its home cage, and the chambers were thoroughly cleaned. There were three sessions in which the animal was injected with normal saline i.p. 30 min prior to each training session, followed by training of each rat by placing it first in the light box. After the training session, the rat was returned to its home cage. Animals that did not cross into the dark box during the training time, despite the practices carried out in training sessions, were eliminated from the study. To evaluate the effect of thujone on acquisition, animals were randomly divided into twelve groups (7-10 rats each) as follows: Experiment 1 (Saline): One group of rats received an injection of saline in the pre-training session on the same day. $24 \mathrm{~h}$ later on the test day, the step-through latencies (STL) were measured. Experiment 2 (acquisition): On the first day, rats of 11 groups were injected with thujone (1.25, 2.5, and $5 \mathrm{mg} / \mathrm{kg}$, i.p.), MLA (10, 20 , or $30 \mu \mathrm{g} / \mathrm{kg}$, i.p. $)$, nicotine $(0.25,0.5$, or $1 \mathrm{mg} / \mathrm{kg}$, i.p. $)$, a combination of thujone $(1.25 \mathrm{mg} / \mathrm{kg}$, i.p. $)+$ nicotine (1 mg/kg,i.p.), or a combination of MLA $(10 \mu \mathrm{g} / \mathrm{kg}$, i.p. $)+$ nicotine $(1 \mathrm{mg} / \mathrm{kg}$,i.p. $)$ in the pre-training session. On the test day (24 hours later), the step-through latencies to enter the dark compartment was measured. Thujone was dissolved in dimethyl sulfoxide (1.5\%), and was administered intraperitoneally, while the placebo control group received only a pre-training injection of dimethyl sulfoxide (1.5\%) (n=8).

2.8.4. Open Field Test: The locomotor activity was investigated using the open field test (OFT) as previously described (Bernaerts et al., 2004; da Silva et al., 2009; Khan et al., 2015; Sadek et al., 2016a; 2016b). The testing arena is a $56 \times 56 \times 56 \mathrm{~cm}$ (length/width/height) rectangular box that is 
open from above. The floor of the box is divided into 32 equal squares ( $14 \mathrm{~cm}$ each side). The 4 central squares are regarded as the "center" of the field. Animals were divided into 6 groups of 6 rats each. They were either injected with saline, thujone $(1.25,2.5$, or $5 \mathrm{mg} / \mathrm{kg}$, i.p.), nicotine (1 $\mathrm{mg} / \mathrm{kg}$, i.p.), or MLA (10 $\mu \mathrm{g} / \mathrm{kg}$, i.p.). Thirty minutes later, rats were transferred to the arena only by their tails and placed in the center where they were allowed to move freely for $3 \mathrm{~min}$. During this time animal activity was recorded by a digital camera placed above the arena. Video recordings were utilized for assessment. When a rat moved from one square to another with its four paws, one line crossing was noted and a distance of $14 \mathrm{~cm}$ was recorded. As previously described, the following parameters were manually scored: the number of lines crossed (defined as at least three paws in a square), total time spent for distance travelled, and time spent in the center and in the periphery of the arena during a 3-min test (Bernaerts et al., 2004; da Silva et al., 2009; Khan et al., 2015; Sadek et al., 2016a; 2016b). Less time spent in the central area is usually taken as a measure of a higher level of anxiety. Thujone was dissolved in dimethyl sulfoxide (1.5\%), and was administered intraperitoneally, while the placebo control group received only a pre-training injection of dimethyl sulfoxide (1.5\%) (n=8). After each test, the arena was sprayed with $70 \%$ ethanol and wiped thoroughly to remove residual odor.

2.8.5. Statistical analysis: $I B M^{\circledR}$ SPSS Statistics ${ }^{\circledR}$ version 20 software (IBM Middle East, Dubai, UAE) was used for all statistical comparisons. Data were expressed as means \pm SEM. The effects of test compounds on acquisition and locomotion were analyzed using two-way analysis of variance (ANOVA) with Treatment (vehicle or thujone) and Dose (thujone; 1.25, 2.5, or $5 \mathrm{mg} / \mathrm{kg}$, i.p.) as the between-subjects factor, and post hoc comparisons were performed with Bonferroni's test in case of a significant main effect. The criterion for statistical significance was set at $\mathrm{P} \leq 0.05$. 
In oocyte experiments, average values were calculated as the mean \pm standard error means (S.E.M.). Statistical significance was analyzed using Student's $t$ test or ANOVA as indicated. Two-way ANOVA was used to analyze the effect of the inhibitors on fractional $\left[{ }^{3} \mathrm{H}\right] \mathrm{NE}$ release. Concentration-response curves were obtained by fitting the data to the logistic equation,

$$
\mathrm{y}=\mathrm{E}_{\max } /\left(1+\left[\mathrm{x} / \mathrm{EC}_{50}\right]^{-\mathrm{n}}\right),
$$

where $\mathrm{x}$ and $\mathrm{y}$ are concentration and response, respectively, $\mathrm{E}_{\max }$ is the maximal response, $\mathrm{EC}_{50}$ is the half-maximal concentration, and $\mathrm{n}$ is the slope factor (apparent Hill coefficient). 


\section{Results}

Bath application of $\mathrm{ACh}(1 \mathrm{mM})$ or thujone $(300 \mu \mathrm{M})$ did not produced detectable currents in oocytes injected with distilled water (30 nl per oocyte, $\mathrm{n}=7$ ). Application of $100 \mu \mathrm{M}$ ACh for 3 to $4 \mathrm{sec}$ activated fast inward currents that desensitized rapidly in oocytes injected with cRNA encoding the $\alpha_{7}$-subunit of human nACh receptor (Fig. 1A). In addition, ACh-induced currents were inhibited completely with $100 \mathrm{nM} \alpha$-bungarotoxin ( $\mathrm{n}=9$, data not shown), indicating that these currents are mediated by the activation of $\alpha_{7}-\mathrm{nACh}$ receptors.

The effect of thujone was tested on ACh $(100 \mu \mathrm{M})$-induced ion currents. An effect of 10 min thujone $(100 \mu \mathrm{M})$ application on $\alpha_{7}$-nACh receptor mediated currents is shown in Fig. 1A. Time-courses of effects of thujone or the vehicle $(0.1 \%$ ethanol) applications on the maximal amplitudes of ACh-induced currents are presented in Fig. 1B. Thujone caused a significant inhibition of the current which was partially reversed during a 10 to 15 min washout. In the absence of thujone, vehicle ( $0.1 \%$ ethanol) alone did not alter the amplitude of the ACh-induced current, suggesting that thujone acts on nACh receptors (Fig. 1B, controls versus thujone treatment group at 10 min of exposure, ANOVA, $\mathrm{n}=6-8 ; \mathrm{P}<0.05)$.

The inhibitory effect of thujone was significantly dependent on the application mode. For example, without preincubation, coapplication of thujone $(100 \mu \mathrm{M})$ and ACh $(100 \mu \mathrm{M})$ did not alter the amplitudes of maximal currents (Fig. 1C). However, when oocytes were preincubated with thujone, the drug was found to inhibit maximal ACh-induced currents in a time dependent manner reaching a maximal level within 5 min with a half-time $\left(\tau_{1 / 2}\right)$ of $1.4 \pm 0.2 \mathrm{~min}$ (Fig. 1C). Since the magnitude of the thujone effect was time-dependent, 10 min thujone application time was used routinely to ensure equilibrium conditions. Thujone was found to inhibit the function of 
$\alpha 7$-nACh receptor in a concentration-dependent manner with an $\mathrm{IC}_{50}$ and slope value of $24.7 \pm 2.1$ $\mu \mathrm{M}$ and $1.1 \pm 0.2$, respectively (Fig. 1D).

Though racemic thujone was employed in the present study, this compound is known to have $\alpha$ and $\beta$ stereo isomers. In earlier studies, $\alpha$-thujone has been shown to be the principal active ingredient of wormwood oil and the toxic component of absinthe (Hold et al., 2000) and have a potency 2-3 times that of $\beta$-thujone on $\mathrm{GABA}_{\mathrm{A}}$ receptors (Hold et al., 2000). We compared the effects of $\alpha$ ( $\beta$ was not commercially available) and racemic ( $\alpha \beta)$ isomers of thujone on $\alpha_{7}$-nACh receptor. The results indicated that there is no significant difference in the extent of inhibition of nicotinic receptors by $100 \mu \mathrm{M}$ of $\alpha$ isomer $(83 \pm 5 \%, \mathrm{n}=8)$ and racemic thujone ( $80 \pm 6 \%, \mathrm{n}=7$, ANOVA P $>0.05)$.

Activation of $\alpha_{7}$-nACh receptors allows sufficient $\mathrm{Ca}^{2+}$ entry to activate endogenous $\mathrm{Ca}^{2+}$-dependent $\mathrm{Cl}^{-}$channels in Xenopus oocytes (Sands et al., 1993; Uteshev, 2012). Therefore, it was important to determine whether the effect of thujone was exerted on nACh receptor mediated currents or on $\mathrm{Cl}^{-}$currents induced by $\mathrm{Ca}^{2+}$ entry. For this reason, we injected the $\mathrm{Ca}^{2+}$ chelator BAPTA into oocytes and replaced extracellular $\mathrm{Ca}^{2+}$ with $\mathrm{Ba}^{2+}$ since $\mathrm{Ba}^{2+}$ can pass through $\alpha_{7}$-nACh receptors but causes less activation of $\mathrm{Ca}^{2+}$-dependent $\mathrm{Cl}^{-}$channels (Sands et al., 1993). Under these conditions, we tested the effect of thujone in a solution containing $2 \mathrm{mM} \mathrm{Ba}^{2+}$ in BAPTA-injected oocytes. Thujone $(100 \mu \mathrm{M})$ produced the same level of inhibition $(79 \pm 6$ in controls versus $74 \pm 8$ in BAPTA-injected oocytes; ANOVA, $\mathrm{P}>0.66 ; \mathrm{n}=6-7$ ) on ACh-induced currents in BAPTA-injected oocytes when currents were recorded in $\mathrm{Ca}^{2+}$ free solution containing $2 \mathrm{mM} \mathrm{Ba}^{2+}$ (Fig. 2A). It is important to mention that in the oocyte expression system, thujone-induced changes in intracellular $\mathrm{Ca}^{2+}$ levels can be attributable to $\mathrm{Ca}^{2+}$-activated $\mathrm{Cl}^{-}$ 
channels and concomitant alterations in the holding currents. However, in control experiments, thujone $(100 \mu \mathrm{M}$ for $10 \mathrm{~min})$ did not alter the magnitudes of holding-currents in oocytes voltage-clamped at $-70 \mathrm{mV}(\mathrm{n}=8)$, indicating that intracellular $\mathrm{Ca}^{2+}$ levels were not altered by thujone.

In the next series of experiments, we examined the effect of membrane potential on thujone-inhibition of $\alpha_{7}$-nACh receptors. Each tested membrane potential was held for 15 to $20 \mathrm{sec}$ and then returned to holding potential of $-70 \mathrm{mV}$. As indicated in Fig. 2B, the inhibition of ACh $(100 \mu \mathrm{M})$-induced currents by thujone $(100 \mu \mathrm{M})$ does not appear to be voltage-dependent. The extent of thujone inhibition was similar at all tested membrane potentials from -120 to $-20 \mathrm{mV}$. Evaluation of the current-voltage relationship (Fig. 2C) indicates that the extent of inhibition by thujone does not change significantly at different test potentials ( $\mathrm{P}>0.05, \mathrm{n}=7$, ANOVA).

Thujone may decrease the binding of the agonist to the receptor by acting as a competitive antagonist. For this reason, we determined the effect of thujone at different ACh concentrations. Concentration-response curves for $\mathrm{ACh}$ in the absence and presence of $100 \mu \mathrm{M}$ thujone are presented in Fig. 3A. In the presence of $100 \mu \mathrm{M}$ thujone, the maximal response induced by ACh decreased significantly $(\mathrm{n}=6-8)$. However, the potency of the $\mathrm{ACh}\left(\mathrm{EC}_{50}\right)$ remained unaltered. In the absence and presence of $\mathrm{ACh}$, the $\mathrm{EC}_{50}$ values were $87 \pm 18 \mu \mathrm{M}$ and $93 \pm 16 \mu \mathrm{M}(\mathrm{P}<0.05$, ANOVA, $n=5-6)$ and slope values were $2.3 \pm 0.4$ and $1.9 \pm 0.3$, respectively, suggesting that thujone inhibits the ACh responses in a noncompetitive manner.

$\left[{ }^{125} \mathrm{I}\right] \alpha$-bungarotoxin competes with $\mathrm{ACh}$, an endogenous activator of $\alpha_{7}-\mathrm{nACh}$ receptors by binding to the ACh binding site on the receptor (Albuquerque et al., 2009). For this reason, the effect of thujone was investigated on the specific binding of $\left[{ }^{125} \mathrm{I}\right] \alpha$-bungarotoxin. Equilibrium 
curves for the binding of $\left[{ }^{125} \mathrm{I}\right] \alpha$-bungarotoxin, in the presence and absence (controls) of thujone are presented in Fig. 3B. At a concentration of $300 \mu \mathrm{M}$, thujone did not cause a significant inhibition of the specific binding of $\left[{ }^{125} \mathrm{I}\right] \alpha$-bungarotoxin. Maximum binding activities $\left(B_{\max }\right)$ of $\left[{ }^{125} \mathrm{I}\right] \alpha$-bungarotoxin were $3.08 \pm 0.23$ and $2.93 \pm 0.31 \mathrm{pM} / \mathrm{mg}$ (means \pm S.E.M.) for controls and thujone-treated preparations, respectively (Fig. 3B). The apparent affinity $\left(K_{\mathrm{D}}\right)$ of the receptor for $\left[{ }^{125} \mathrm{I}\right] \alpha$-bungarotoxin was $0.71 \pm 0.16$ and $0.76 \pm 0.21 \mathrm{pM}$ for controls and thujone, respectively. There was no statistically significant difference between controls and thujone-treated groups with respect to $K_{\mathrm{D}}$ and $B_{\max }$ values ( $\mathrm{P}>0.05$, ANOVA, n=6-7) suggesting that thujone does not compete with $\alpha$-bungarotoxin at the same binding site.

We have also tested the effect of thujone $(100 \mu \mathrm{M})$ on choline-induced $\mathrm{Ca}^{2+}$ transients in SH-EP1 cells stably transfected with human $\alpha_{7}$-nACh receptor. In SH-EP1 cells loaded with Fluo-4 $\mathrm{AM}$, focal application of $10 \mathrm{mM}$ choline, a selective agonist for $\alpha_{7}$-nACh receptor (Albuquerque et al., 2009) for a short duration ( $30 \mathrm{sec}$ ) caused a rapid increase in the intracellular $\mathrm{Ca}^{2+}$ transient (Fig. 4A) that was significantly inhibited by $10 \mathrm{~min}$. preincubation with $100 \mu \mathrm{M}$ thujone and completely suppressed by $1 \mu \mathrm{M}$ methyllycaconitine (MLA), a selective antagonist for $\alpha_{7}$-nACh receptor (Fig. 4B). Increasing concentrations of thujone caused a concentration-dependent inhibition of choline-induced $\mathrm{Ca}^{2+}$ transients with $\mathrm{IC}_{50}$ value of $26 \mu \mathrm{M}$ (Fig. 4C). The effects of thujone $(100 \mu \mathrm{M})$ on the functional properties of other neuronal nACh receptor subtypes were also examined on current responses mediated by different subunit combinations expressed in Xenopus oocytes. Although, $\alpha 4 \beta 2$ subunits were significantly inhibited, the overall effect of thujone was considerably less on other subunit combinations (Fig. 4D).

Long-term potentiation (LTP) of glutamatergic synapses in the hippocampus has been 
considered a cellular correlate of learning and memory. In earlier studies, it has been shown that nicotine causes a significant enhancement of LTP by activating $\alpha_{7}$-nACh receptor in the dentate gyrus of the hippocampus (Welsby et al., 2006; 2007). For this reason, we have investigated whether thujone effects nicotine-induced enhancement of LTP in the dentate gyrus. In agreement with earlier studies (Welsby et al., 2006; 2007), delivery of high frequency stimulation (HFS) to the presynaptic medial perforant pathway induced an LTP of field excitatory post-synaptic potentials (fEPSPs) and application of nicotine $(5 \mu \mathrm{M}) 5 \mathrm{~min}$. prior to HFS caused a further increase of amplitudes and slopes of fEPSPs compared to slices simulated with HFS alone (Fig. 5A and 5B). In another set of slices thujone $(100 \mu \mathrm{M})$ preapplied $5 \mathrm{~min}$. before the application of nicotine (5 $\mu \mathrm{M})$ and thujone. In thujone treated slices potentiation of LTP by nicotine was completely inhibited (Fig. 5A). Summary of the results of LTP experiments was shown in Fig. 5B. In agreement with earlier studies (Welsby et al., 2006; 2007) 5 min pretreatment with MLA $(1 \mu \mathrm{M})$, a selective antagonist of $\alpha_{7}$-nACh receptor also suppressed the potentiation of LTP by nicotine.

In the next series of experiments, the effects of thujone, MLA, and nicotine on acquisition in passive avoidance conditioned response were investigated. Fig. 6A-C shows the effect of thujone $(1.25,2.5$ and $5 \mathrm{mg} / \mathrm{kg})$, MLA $(10,20$, and $30 \mu \mathrm{g} / \mathrm{kg})$, and nicotine $(0.25,0.5$, and 1 $\mathrm{mg} / \mathrm{kg}$ ), on acquisition in an inhibitory avoidance conditioned response in rats. One-way analysis of variance showed that treatment with thujone $(1.25,2.5$ and $5 \mathrm{mg} / \mathrm{kg})$, MLA $(10,20$, and 30 $\mu \mathrm{g} / \mathrm{kg})$, and nicotine $(0.25,0.5$, and $1 \mathrm{mg} / \mathrm{kg})$ exerted a significant effect on step-through latencies (STLs) $\left[F_{(9,60)}=4.67 ; \mathrm{P}<0.001\right]$ when injected before the acquisition test. As revealed by subsequent post hoc tests, thujone $(1.25,2.5$, and $5 \mathrm{mg} / \mathrm{kg})$ did not impair latency time when compared to the (saline)-treated group with $\left[F_{(1,12)}=0.003 ; \mathrm{P}=0.955\right],\left[F_{(1,12)}=0.364 ; \mathrm{p}=0.557\right]$, and 
$\left[F_{(1,12)}=1.699 ; \mathrm{P}=0.217\right]$, respectively. However, MLA tested at doses $(10$ and $30 \mu \mathrm{g} / \mathrm{kg})$ showed significantly impaired STLs when compared to (Saline)-treated group with $\left[F_{(1,12)}=5.197 ; \mathrm{P}<0.05\right]$ and $\left[F_{(1,12)}=7.839 ; \mathrm{p}<0.05\right]$, respectively. Moreover, nicotine $(1 \mathrm{mg} / \mathrm{kg})$, significantly improved memory at the level of acquisition when compared (Saline)-treated group with $\left[F_{(1,12)}=9.167\right.$; $\mathrm{P}<0.05]$, whereas lower doses of nicotine $(0.25$ and $0.5 \mathrm{mg} / \mathrm{kg})$ failed to significantly improve memory acquisition when compared to (Saline)-treated group with $\left[F_{(1,12)}=0.836 ; \mathrm{P}=0.379\right]$ and $\left[F_{(1,12)}=1.538 ; \mathrm{P}=0.239\right]$, respectively. Notably, thujone $(1.25 \mathrm{mg} / \mathrm{kg})$ and MLA $(10 \mu \mathrm{g} / \mathrm{kg})$ reversed the memory-enhancing effect provided by nicotine $(1 \mathrm{mg} / \mathrm{kg})$ as revealed with $\left[F_{(1,12)}=0.947 ; \mathrm{P}=0.350\right]$ and $\left[F_{(1,12)}=0.232 ; \mathrm{P}=0.639\right]$ for nicotine $(1 \mathrm{mg})+$ thujone $(1.25$ $\mathrm{mg})$-treated group vs (Saline)-treated group and nicotine $(1 \mathrm{mg})+$ MLA $(10 \mu \mathrm{g})$-treated group vs (Saline)-treated group, respectively Fig. 6C.

In the next series of experiments, effects of thujone, MLA, and nicotine were tested on locomotion in an open field test (OFT). We used the OFT to rule out possible intrinsic impairment of spontaneous locomotor activity or anxiety measures. Locomotor activity was measured by the distance travelled and number of line crossings in the arena. One-way analysis of variance revealed that thujone (1.25, 2.5, and $5 \mathrm{mg} / \mathrm{kg}$, i.p.), nicotine ( $1 \mathrm{mg} / \mathrm{kg}$, i.p.), and MLA (10 $\mu \mathrm{g} / \mathrm{kg}$, i.p.) had no effect on distance travelled and number of line crossings as compared to the (Saline)-treated group with $\left[F_{(1,10)}=0.011 ; \mathrm{P}=0.917\right], \quad\left[F_{(1,10)}=0.329 ; \mathrm{P}=0.579\right], \quad\left[F_{(1,10)}=0.076 ; \mathrm{P}=0.788\right]$, $\left[F_{(1,10)}=0.564 ; \mathrm{P}=0.470\right]$, and $\left[F_{(1,10)}=0.257 ; \mathrm{P}=0.623\right]$, respectively (Fig.7A and 7B). Similarly, no significant treatment differences were found with regard to time spent in the central area or periphery (all $\mathrm{P}>0.05$ ) (Fig. 7C). 


\section{Discussion}

In the present study, using electrophysiological, biochemical and behavioral methods, we provide evidence that thujone inhibits the function of human $\alpha_{7}-\mathrm{nACh}$ receptors expressed in Xenopus oocytes and SH-EP1 cells and suppresses cellular and behavioral correlates of nicotine-induced learning and memory formation. Inhibition by thujone is reversible and occurs in a time and concentration dependent manner, but independent of membrane potential and intracellular $\mathrm{Ca}^{2+}$ levels.

In Xenopus oocytes, activation of $\alpha_{7}$-nACh receptors, due to their high $\mathrm{Ca}^{2+}$ permeability, allows sufficient $\mathrm{Ca}^{2+}$ entry to activate endogenous $\mathrm{Ca}^{2+}$-dependent $\mathrm{Cl}^{-}$channels (Hartzell et al., 2005; Sands et al., 1993). Therefore, the direct actions of thujone on $\mathrm{Ca}^{2+}$-dependent $\mathrm{Cl}^{-}$channels may contribute to the observed effects of thujone on ACh-activated currents in this expression system. In oocytes injected with BAPTA and recorded in a solution containing $2 \mathrm{mM} \mathrm{Ba}^{2+}$, thujone continued to inhibit $\alpha_{7}$-nACh receptor-mediated ion currents, suggesting that $\mathrm{Ca}^{2+}$-dependent $\mathrm{Cl}^{-}$ channels were not involved in thujone inhibition of nicotinic responses. In addition, the reversal potential in solutions containing $\mathrm{Ba}^{2+}$ was not altered in the presence of thujone, suggesting that the inhibitory effect of thujone is not due to alterations in the $\mathrm{Ca}^{2+}$ permeability of the $\alpha_{7}$-nACh receptor-channel complex. Furthermore, since $\mathrm{Ca}^{2+}$-activated $\mathrm{Cl}^{-}$channels are highly sensitive to intracellular $\mathrm{Ca}^{2+}$ levels $\left(\mathrm{K}_{\mathrm{D}}\right.$ of $\mathrm{Ca}^{2+}$-activated $\mathrm{Cl}^{-}$channels for $\mathrm{Ca}^{2+}$ is less than $1 \mu \mathrm{M}$, for a review (Hartzell et al., 2005), alterations in intracellular $\mathrm{Ca}^{2+}$ levels would be reflected by changes in the holding current under voltage-clamp conditions. However, during our experiments, application of thujone $(300 \mu \mathrm{M})$, did not cause alterations in baseline or holding currents, suggesting that thujone does not affect intracellular $\mathrm{Ca}^{2+}$ concentrations. Similarly, intracellular $\mathrm{Ca}^{2+}$ levels were not 
altered in the presence of thujone alone $(100 \mu \mathrm{M})$ in SH-EP1 cells (unpublished results, $n=4)$.

In this study, thujone was applied in the concentration range of $3 \mu \mathrm{M}$ to $1 \mathrm{mM}$ and was found to inhibit the function of $\alpha_{7}$-nACh receptors in a concentration-dependent manner $\left(\mathrm{IC}_{50}\right.$ value of $24.7 \mu \mathrm{M})$. The concentration of thujone in plasma and its ability to pass the blood brain barrier following oral and intravenous administration has been studied previously (Waidyanatha et al., 2013). Doses of $\alpha$-thujone (1.6 mg/kg, I.V.) used in in-vivo studies (Waidyanatha et al., 2013) found to promote thujone blood level of $3.7 \mu \mathrm{M}$. Since thujone is a highly lipophilic compound with $\operatorname{LogP}$ (octanol-water partition coefficient) value of 2.7 (Barceloux, 2012; Mariani et al., 2016), its membrane concentration is expected to be considerably higher than blood levels. Furthermore, brain plasma ratios for $\alpha$-thujone have been shown to be in the range of 4 to 6 (Waidyanatha et al., 2013). Therefore, the functional modulation of $\alpha_{7}$-nACh receptors demonstrated in this study can be pharmacologically relevant.

Previous studies have demonstrated that thujone acts on several integral membrane proteins including $\mathrm{GABA}_{\mathrm{A}}$ receptors (Hold et al., $\mathrm{IC}_{50}=21 \mu \mathrm{M}$; Szczot et al., 2012, 100-300 $\mu \mathrm{M}$; Czyzewska et al., 2013, 100-300 $\mu \mathrm{M}$; Sanchez-Borzone et al., $\left.\mathrm{EC}_{50}=75 \mu \mathrm{M}\right), 5-\mathrm{HT}_{3}$ receptors (Deiml et al., 2004; $\mathrm{IC}_{50}=60 \mu \mathrm{M}$ ). It is plausible that thujone acts as an allosteric modulator for various receptors and ion channels at the lipid membrane accounting for some of its epileptogenic, psychogenic, and anti-inflammatory actions (Holstege et al.,2002; Lachenmeier, 2010; Olsen, 2000; Pelkonen et al., 2013).

Open-channel blockade is a widely used model to describe the block of ligand-gated ion channels (Hille, 2001). However, this model cannot account for the results of the present study. Firstly, for open channel blockers, the presence of the agonist is required to allow the blocker to 
enter the channel after an agonist-induced conformational change. In contrast to open channel blockers, preincubation was found to augment thujone's effect on $\alpha_{7}$-nACh receptor activity (Fig. 1), suggesting that thujone interacts with the closed state of the receptor. Secondly, inhibition by thujone is not voltage sensitive, suggesting that the thujone-binding site is not affected by the transmembrane electric field. Thirdly, thujone had little effect when co-administered with ACh without thujone preincubation (only coapplication data in Fig. 1 C).

Allosteric modulators alter the functional properties of ligand-gated-ion channels by interacting with site(s) that are topographically distinct from the ligand binding sites (for a review; (Onaran and Costa, 2009). In electrophysiological studies, although the potency of ACh, a natural ligand (agonist) for the receptor, was not altered, its efficacy was significantly inhibited by thujone, indicating that thujone did not compete with the ACh binding site on the receptor. In agreement with these findings, radioligand binding studies indicated that the specific binding characteristics of $\left[{ }^{125} I\right] \alpha$-bungarotoxin were not affected by thujone, further suggesting that thujone does not interact with the ACh binding site on the receptor. Collectively, these findings indicate that thujone acts as an allosteric inhibitor of the $\alpha_{7}$-nACh receptor i.e., thujone binds to site(s) topographically distinct from the ACh binding sites on the receptor-ion channel complex.

It is likely that thujone, a highly lipophilic agent, first dissolves into the lipid membrane and then diffuses into a non-annular lipid space to inhibit the ion channel-receptor complex. Consistent with this idea, the effect of thujone on $\alpha_{7}$-nACh receptor reached a maximal level within 10-15 min of application. Similarly, actions of several hydrophobic allosteric modulators such as cannabinoids (Oz et al., 2004c; Spivak et al., 2007; Butt et al., 2008), general anesthetics (Jackson et al., 2008; Zhang et al., 1997), monoterpenes (Lozon et al., 2016) on ligand-gated ion 
channels require 5-20 min to reach their maxima (for reviews, Oz, 2006; Oz et al., 2015), suggesting that the binding site(s) for these allosteric modifiers is located inside the lipid membrane and require a relatively slow (in minutes) time course to modulate the function of the receptor. It is likely that these hydrophobic agents affect the energy requirements for gating-related conformational changes in ligand-gated ion channels (Spivak et al., 2007).

Memory is often considered to be a process that has several stages including acquisition, consolidation, and retrieval (Abel and Lattal, 2001). Generally, some tasks that have been considered to modulate memory processes involve a training session followed, after 24 or more hours, by a test session. In the current study, acute systemic administration of thujone $(1.25,2.5$, and $5 \mathrm{mg} / \mathrm{kg}$ ) failed to modulate memory acquisition when compared with the saline-treated group. Thujone may not be effective since it is not as potent as MLA and dose of thujone (when applied alone) may not be high enough to exert an in-vivo memory-modulating effect (Fig. 6B). However, the selective competitive $\alpha_{7}$-nACh receptor antagonist MLA (10 and $30 \mu \mathrm{g} / \mathrm{kg}$ ) impaired acquisition, indicating that $\alpha_{7}-\mathrm{nACh}$ receptors are, in addition to other several neural circuits, involved in the memory-enhancing effect at the level of acquisition (Fig. 6B). In contrast, our results showed that acute systemic administration of nicotine $(1 \mathrm{mg} / \mathrm{kg}$, i.p.) in the pre-training session facilitated acquisition (Fig. 6A). These results are in agreement with previous findings highlighting the memory-enhancing role of nicotine in acquisition as a stage of memory processing (Rangani et al., 2012). Interestingly, the procognitive activity of nicotine (1 mg/kg, i.p.) on acquisition was in a further experiment completely reversed when rats were pretreated with thujone (1.25 mg/kg, i.p.) or the selective competitive $\alpha_{7}-\mathrm{nAChR}$ antagonist MLA (10 mg/kg, i.p.), indicating that cholinergic pathways through activation of $\alpha_{7}-\mathrm{nACh}$ receptors appear to be 
participating in neuronal circuits involved in memory processes (Fig. 6C). The latter observation is in agreement with previous studies in which nicotine treatment improved cognition whereas administration of MLA blocked the neuroprotective effect of nicotine during chronic stress (Alzoubi et al., 2013; Potasiewicz et al., 2015). These results strongly suggest the involvement of $\alpha_{7}$-nAChRs in the neuroprotective effect of nicotine.

Notably, the results observed in the current study for thujone at doses of $1.25,2.5$, and 5 $\mathrm{mg} / \mathrm{kg}$, i.p., did not affect spontaneous locomotor activity (Fig. 7A and 7B) and anxiety levels of male Wistar rats. This finding is significant, since enhanced performance in an inhibitory avoidance task can be the result of many variables unrelated to memory acquisition such as changes in spontaneous locomotor activity or emotional response (Charlier et al., 2013; McGaugh and Roozendaal, 2009; Sadek et al., 2016a). Therefore, it is unlikely that thujone administered before the conditioning session reversed the memory-enhancing effect of nicotine through a nonspecific effect during the training session. The results suggest that acute systemic administration of thujone in the pre-training sessions impairs cognitive enhancement of nicotine during acquisition. Moreover, our results add further support to the therapeutic potential of $\alpha_{7}$-nACh receptors in the treatment of neuropsychiatric diseases, especially those characterized by deficits affecting several stages of memory processing, e.g. epilepsy Alzheimer's disease, schizophrenia, and attention deficit hyperactivity disorder. However, additional experiments should be conducted with a battery of behavioral tests and with different animal strains to increase the validity and the translational value of the current findings.

In conclusion, this study establishes that thujone acts at the noncompetitive blocker site of the $\alpha 7$-nACh receptors, and provides evidence for inhibitory actions of thujone on 
nicotine-induced enhancement of LTP and nicotine-induced changes in behavioral assays on learning and memory formation and allows more meaningful evaluation of risk mechanisms involved in the continued use of herbal medicines containing thujone.

\section{Acknowledements:}

The research in this study was supported by grants from CMHS, UAE University. The authors gratefully acknowledge Dr. Jon Lindstrom (University of Pennsylvania, PA, USA) for providing cDNA clones of the human $\alpha_{7}$-nACh receptor subunit, Dr. Isabel Bermudez-Diaz (Oxford Brookes University, Oxford, UK) for human $\alpha_{4}, \alpha_{3}, \beta_{2}$, and $\beta_{4}$ subunits, and Dr. R Lukas (Barrow Neurological Institute, Phoenix, AZ, USA) for SH-EP1 cells stably expressing the human $\alpha_{7} \mathrm{nAChR}$. 


\section{FIGURE LEGENDS}

Figure 1. Effects of thujone on $\alpha_{7}$-nicotinic acetylcholine receptor. (A) Records of currents activated by acetylcholine (ACh, $100 \mu \mathrm{M}$ ) in control conditions (left), after 10 min pretreatment with thujone $(100 \mu \mathrm{M})$ co-application of $100 \mu \mathrm{M}$ thujone $\mathrm{ACh}$ (middle), and 15 min washout (right). (B) Time-course of the effect of vehicle ( $0.1 \%$ ethanol; filled circles) and thujone $(100 \mu \mathrm{M}$; open circles) on the maximal amplitudes of the ACh-induced currents. Each data point represents the normalized mean \pm S.E.M. of 6 to 8 experiments. The horizontal bar in the figure indicates the duration of thujone or vehicle application. (C) Effect of thujone as a function of thujone pre-application time. Prolongation of thujone pre-application time significantly increases the inhibition of $\alpha_{7}$-nACh receptor. Each data point represents the mean \pm S.E.M. of 6 to 7 oocytes. (D) Thujone inhibits $\alpha_{7}$-nACh receptor function in a concentration-dependent manner. Each data point represents the mean \pm S.E.M. of 6 to 9 oocytes. The curve is the best fit of the data to the logistic equation described in the methods section.

Figure 2. Effects of thujone on nACh receptors are not dependent on intracellular $\mathrm{Ca}^{2+}$ levels and changes in membrane potential. (A) Bar presentation of the effects of $100 \mu \mathrm{M}$ thujone application (10 min) on the maximal amplitudes of ACh induced currents in oocytes injected with $50 \mathrm{nl}$ distilled-water, controls $(\mathrm{n}=5)$ or BAPTA $(50 \mathrm{nl}, 200 \mathrm{mM}, \mathrm{n}=7)$. Bars represent the means \pm S.E.M. of 5 to 7 experiments. (B) Current-voltage relationships of acetylcholine-activated currents in the absence and presence of thujone. Normalized currents activated by $100 \mu \mathrm{M}$ ACh before (control, filled circles) and after 10 min treatment with $100 \mu \mathrm{M}$ thujone (open circles). Each data point presents the normalized means and S.E.M. of five to six experiments. (C) Quantitative presentation of the effect of thujone as percent inhibition at different voltages. 
Figure 3. Concentration-response curves for acetylcholine-induced currents and binding of $\left[{ }^{125} \mathrm{I}\right]$ $\alpha$-bungarotoxin in control and in the presence of thujone. (A) Effect of thujone on the acetylcholine $(\mathrm{ACh})$ concentration-response relationship. Oocytes were voltage-clamped at -70 $\mathrm{mV}$ and currents were activated by applying $\mathrm{ACh}(1 \mu \mathrm{M}$ to $3 \mathrm{mM})$. Oocytes were exposed to 100 $\mu \mathrm{M}$ thujone for 10 min and $\mathrm{ACh}$ was reapplied. Paired concentration-response curves were constructed and responses normalized to maximal response under control conditions. Data points obtained before (control) and after 10 min treatment with thujone $(100 \mu \mathrm{M})$ are indicated by filled and open circles, respectively. Each data point presents the normalized means and S.E.M. of 8 to 12 experiments. (B) The effects of thujone on the specific binding of $\left[{ }^{125} \mathrm{I}\right] \alpha$-bungarotoxin to oocyte membrane preparations. In the presence and absence of thujone, specific binding as a function of the concentration of $\left[{ }^{125} \mathrm{I}\right] \alpha$-bungarotoxin is presented. Data points for controls and thujone $(300 \mu \mathrm{M})$ are indicated by filled and open circles, respectively. Data points are the means of three independent experiments carried out in triplicate.

Figure 4. The effects of thujone on choline-induced intracellular $\mathrm{Ca}^{2+}$ transients in SH-EP1 cells and neuronal $\alpha_{7}$-nACh receptor subtypes expressed in Xenopus oocytes. (A) The effect of thujone $(100 \mu \mathrm{M})$ and methyllycaconitine (MLA, $1 \mu \mathrm{M}$ ), a selective antagonist for $\alpha_{7}$-nACh receptor, on choline-induced intracellular $\mathrm{Ca}^{2+}$ transients in SH-EP1 cells loaded with $10 \mu \mathrm{M}$ Fluo-4 AM. (B) Summary of the effects of thujone and MLA on the area under choline-induced $\mathrm{Ca}^{2+}$ transients from 5 to 6 experiments. (C) Concentration-inhibition curve for the effect of thujone on the area under choline-induced $\mathrm{Ca}^{2+}$ transients. Each data point presents the normalized means and S.E.M. of 4 to 6 experiments. The curve is the best fit of the data to the logistic equation described in the methods section. (D) Comparison of the inhibitory effect of $100 \mu \mathrm{M}$ thujone on ACh (100 
$\mu \mathrm{M})$-induced currents mediated by $\alpha_{7}, \alpha_{4} \beta_{2}, \alpha_{3} \beta_{4}, \alpha_{3} \beta_{2}$, and $\alpha_{4} \beta_{4}$ subunits. Bars represent the mean inhibition \pm S.E.M. from 7 to 9 experiments.

Figure 5. Thujone inhibits nicotine-induced potentiation of LTP in the dentate gyrus of the hippocampus. (A) Recordings of field excitatory post synaptic potentials (fEPSPs) are shown in three sets of experiments. On the left: fEPSPs recorded before and $60 \mathrm{~min}$ after delivery of high frequency stimulation (HFS). In the middle: fEPSPs recorded and 5 min nicotine $(5 \mu \mathrm{M})$ was applied prior to delivery of HFS. Recordings show before and 60 min after nicotine and HFS. On the right: Thujone $(100 \mu \mathrm{M})$ was applied $10 \mathrm{~min}$ before nicotine application. Nicotine was coapplied with thujone and then HFS was delivered. (B) Results of experiments showing the mean effect of nicotine in the presence and absence of thujone. Each data point represents the normalized mean \pm S.E.M. of 8 -11 slices.

Figure 6. Effect of pre-training administration of nicotine, thujone, and MLA on memory acquisition in an inhibitory avoidance conditioned response in male Wistar rats. Gray columns represent the mean step-through latencies measured during the test (test latencies) and black columns represent the mean step-through latencies measured during the training trial before the delivery of the foot-shock (pre-shock latencies). (A) Rats were injected with nicotine $(0.25,0.5$ or $1 \mathrm{mg} / \mathrm{kg}$, i.p.) $30 \mathrm{~min}$ before the training session. Memory retention was measured $24 \mathrm{~h}$ after training. (B) Rats were injected with thujone (1.25, $2.5 \mathrm{or} 5 \mathrm{mg} / \mathrm{kg}$, i.p.) or with MLA (10, 20 or 30 $\mu \mathrm{g} / \mathrm{kg}$, i.p.) $30 \mathrm{~min}$ before the training session. Memory retention was measured $24 \mathrm{~h}$ after training. (C) Rats were injected with a combination of nicotine (1 mg/kg, i.p.) and thujone $(1.25 \mathrm{mg} / \mathrm{kg}$, i.p.) or MLA (10 $\mu \mathrm{g} / \mathrm{kg}$, i.p.) $30 \mathrm{~min}$ before the training session. Memory retention was measured $24 \mathrm{~h}$ after training. ${ }^{*} P<0.005$ for mean step-through latencies vs. the value of the saline group. 
Data are expressed as mean $\pm \operatorname{SEM}(\mathrm{n}=7)$.

Figure 7. Number of line crossings (A), total distance travelled (B), and time spent in the center and periphery $(\mathbf{C})$ in the area of an open field following acute systemic administration of nicotine, thujone, or MLA. In the open field test, nicotine ( $1 \mathrm{mg} / \mathrm{kg}$, i.p.), Thujone $(1.205,2.5$, or $5 \mathrm{mg} / \mathrm{kg}$, i.p.), or MLA (10 $\mu \mathrm{g} / \mathrm{kg}$, i.p.) had no effect on number of line crossings (A), total distance travelled (B), and time spent in the center or periphery (C). Data are expressed as mean $\pm \operatorname{SEM}(\mathrm{n}=6)$. 


\section{REFERENCES}

Abel, T., Lattal, K. M., 2001. Molecular mechanisms of memory acquisition, consolidation and retrieval. Curr Opin Neurobiol 11, 180-187.

Albuquerque, E. X., Pereira, E. F., Alkondon, M., Rogers, S. W., 2009. Mammalian nicotinic acetylcholine receptors: from structure to function. Physiol Rev, 89, 73-120.

Alzoubi, K. H., Srivareerat, M., Tran, T. T., Alkadhi, K. A., 2013. Role of alpha7- and alpha4beta2-nAChRs in the neuroprotective effect of nicotine in stress-induced impairment of hippocampus-dependent memory. Int. J. Neuropsychopharmacol. 16, 1105-1113.

Barceloux, D..G., 2012. Medical Toxicology of Drug Abuse: Synthesized Chemicals and Psychoactive Plants. John Wiley \& Sons, Inc., Hoboken, New Jersey, USA.

Bernaerts, P., Lamberty, Y., Tirelli, E., 2004. Histamine H3 antagonist thioperamide dose-dependently enhances memory consolidation and reverses amnesia induced by dizocilpine or scopolamine in a one-trial inhibitory avoidance task in mice. Behav. Brain Res. 154, 211-219.

Brauneis U, Oz M, Peoples RW, Weight FF, Zhang L. (1996) Differential sensitivity of recombinant N-methyl-D-aspartate receptor subunits to inhibition by dynorphin. JPET, 279: 1063-1068.

Butt C, Alptekin A, Shippenberg T, Oz M. (2008) Endogenous cannabinoid anandamide inhibits nicotinic acetylcholine receptor function in mouse thalamic synaptosomes. J Neurochem. 105:1235-1243.

Charlier, Y., Brabant, C., Serrano, M. E., Lamberty, Y., Tirelli, E., 2013. The prototypical histamine $\mathrm{H} 3$ receptor inverse agonist thioperamide improves multiple aspects of memory processing in an inhibitory avoidance task. Behav Brain Res 253, 121-127.

Czyzewska, M.M., Mozrzymas, J.W., 2013. Monoterpene $\alpha$-thujone exerts a differential inhibitory action on GABA(A) receptors implicated in phasic and tonic GABAergic inhibition. Eur. J. Pharmacol.. 702, 38-43.

da Silva, A. L., Silva Martins, B., Linck Vde, M., Herrmann, A. P., Mai, N., Nunes, D. S., Elisabetsky, E., 2009. MK801- and scopolamine-induced amnesias are reversed by an Amazonian herbal locally used as a "brain tonic". Psychopharmacology (Berl) 202, 165-172.

Deiml T, Haseneder R, Zieglgänsberger W, Rammes G, Eisensamer B, Rupprecht R, Hapfelmeier G. (2004) Alpha-thujone reduces 5-HT3 receptor activity by an effect on the agonist-reduced desensitization. Neuropharmacology. 46: 192-201. 
Dettling, A., Grass, H., Schuff, A., Skopp, G., Strohbeck-Kuehner, P., Haffner, H.T..2004. Absinthe: attention performance and mood under the influence of thujone. J. Stud. Alcohol. 65, 573-581.

Gambelunghe, C., Melai, P. 2002. Absinthe: enjoying a new popularity among young people? Forensic Sci. Int. 130, 183-186.

Hartzell, C., Putzier, I., Arreola, J., 2005. Calcium-activated chloride channels. Annu. Rev. Physiol. 67, 719-758.

Hall, A.C., Turcotte, C.M., Betts, B.A., Yeung, W.Y., Agyeman, A.S., Burk, L.A. 2004. Modulation of human GABAA and glycine receptor currents by menthol and related monoterpenoids. Eur. J. Pharmacol. 506, 9-16.

Hille, B., 2001. Ion Channels of Excitable Membranes. Sinauer Associates Inc., Sunderland, MA

Hoffman AF, Oz M, Yang R, Lichtman AH, Lupica CR. (2007) Opposing actions of chronic $\Delta$ 9-tetrahydrocannabinol and cannabinoid antagonists on hippocampal long-term potentiation. Learning \& Memory 14: 63-74

Holstege CP, Baylor MR, Rusyniak DE.(2002) Absinthe: return of the Green Fairy. Semin Neurol. 22:89-93.

Hogg, R. C., Raggenbass, M., Bertrand, D., 2003. Nicotinic acetylcholine receptors: from structure to brain function. Rev. Physiol. Biochem. Pharmacol. 147, 1-46.

Höld KM, Sirisoma NS, Ikeda T, Narahashi T, Casida JE. (2000) Alpha-thujone (the active component of absinthe): gamma-aminobutyric acid type A receptor modulation and metabolic detoxification. Proc Natl Acad Sci U S A. 97:3826-3831.

Jackson SN, SK Singhal SK, AS Woods AS, M Morales M, T Shippenberg T, L Zhang L, Oz M. (2008) Volatile anesthetics and endogenous cannabinoid anandamide have additive and independent inhibitory effects on $\alpha$ 7-nicotinic acetylcholine receptor-mediated responses in Xenopus oocytes. Eur. J. Pharmacol. 582: 42-51

Khan, N., Saad, A., Nurulain, S. M., Darras, F. H., Decker, M., Sadek, B., 2015. The dual-acting $\mathrm{H} 3$ receptor antagonist and $\mathrm{AChE}$ inhibitor UW-MD-71 dose-dependently enhances memory retrieval and reverses dizocilpine-induced memory impairment in rats. Behav. Brain Res. 297, 155-164.

Lachenmeier, D.W., 2010. Wormwood (Artemisia absinthium L.)--a curious plant with both neurotoxic and neuroprotective properties? J. Ethnopharmacol. 131, 224-227. 
Lozon, Y., Sultan, A., Lansdell, S.J., Prytkova, T., Sadek, B., Yang, K.H., Howarth, F.C., Millar, N.S., Oz, M. 2016. Inhibition of human $\alpha 7$ nicotinic acetylcholine receptors by cyclic monoterpene carveol. Eur. J. Pharmacol. 776, 44-51.

Mahgoub M, Keun-Hang SY, Sydorenko V, Ashoor A, Kabbani N, Al Kury L, Sadek B, Howarth CF, Isaev D, Galadari S, Oz M. (2013) Effects of cannabidiol on the function of $\alpha$ 7-nicotinic acetylcholine receptors. Eur J Pharmacol. 720: 310-319.

Mariani, M.E., Sánchez-Borzone, M.E., García, D.A., 2016. Effects of bioactive monoterpenic ketones on membrane organization. A langmuir film study. Chem. Phys. Lipids. 198, 39-45.

McGaugh, J. L., Roozendaal, B., 2009. Drug enhancement of memory consolidation: historical perspective and neurobiological implications. Psychopharmacology (Berl) 202, 3-14.

Olsen, R.W., 2000. Absinthe and gamma-aminobutyric acid receptors. Proc Natl Acad Sci U S A. 97, 4417-4418.

Onaran, H. O., Costa, T., 2009. Allosteric coupling and conformational fluctuations in proteins. Curr. Protein. Pept. Sci. 10, 110-115.

Oz, M., 2006. Receptor-independent actions of cannabinoids on cell membranes: focus on.endocannabinoids. Pharmacol. Ther. 111, 114-144.

Oz M, Lozon Y, Sultan A, Yang KH, Galadari S. (2015) Effects of monoterpenes on ion channels of excitable cells. Pharmacol Ther. 152: 83-97.

Oz, M., Melia, M. T., Soldatov, N. M., Abernethy, D. R., Morad, M., 1998. Functional coupling of human L-type $\mathrm{Ca} 2+$ channels and angiotensin AT1 A receptors coexpressed in xenopus laevis oocytes: involvement of the carboxyl-terminal Ca2+ sensors. Mol. Pharmacol. 54, 1106-1112.

Oz M, Spivak CE and Lupica CR (2004a) The solubilizing detergents, Tween 80 and Triton X-100 non-competitively inhibit alpha 7-nicotinic acetylcholine receptor function in Xenopus oocytes. J Neurosci Methods 137:167-173.

Oz, M., Zakharova, I., Dinc, M., Shippenberg, T., 2004b. Cocaine inhibits cromakalim-activated $\mathrm{K}+$ currents in follicle-enclosed Xenopus oocytes. Naunyn Schmiedebergs Arch. Pharmacol. 369, 252-259.

Oz, M., Zhang, L., Ravindran, A., Morales, M., Lupica, C. R., 2004c. Differential effects of endogenous and synthetic cannabinoids on alpha7-nicotinic. J. Pharmacol. Exp. Ther. 310, $1152-1160$. 
Pelkonen, O., Abass, K., Wiesner, J., 2013. Thujone and thujone-containing herbal medicinal and botanical products: toxicological assessment. Regul. Toxicol. Pharmacol.. 65, 100-107

Potasiewicz, A., Kos, T., Ravazzini, F., Puia, G., Arias, H. R., Popik, P., Nikiforuk, A., 2015. Pro-cognitive activity in rats of 3-furan-2-yl-N-p-tolyl-acrylamide, a positive allosteric modulator of the alpha7 nicotinic acetylcholine receptor. Br J Pharmacol 172, 5123-5135.

Rangani, R. J., Upadhya, M. A., Nakhate, K. T., Kokare, D. M., Subhedar, N. K., 2012. Nicotine evoked improvement in learning and memory is mediated through NPY Y1 receptors in rat model of Alzheimer's disease. Peptides 33, 317-328.

Rivera, E.M., Cid, M.P., Zunino, P., Baiardi, G., Salvatierra, N.A.. 2014. Central $\alpha$ - and $\beta$-thujone: similar anxiogenic-like effects and differential modulation on GABAA receptors in neonatal chicks. Brain Res. 1555, 28-35.

Sadek, B., Khan, N., Darras, F. H., Pockes, S., Decker, M., 2016a. The dual-acting AChE inhibitor and $\mathrm{H} 3$ receptor antagonist UW-MD-72 reverses amnesia induced by scopolamine or dizocilpine in passive avoidance paradigm in rats. Physiol. Behav. 165, 383-391.

Sadek, B., Saad, A., Subramanian, D., Shafiullah, M., Lazewska, D., Kiec-Kononowiczc, K., 2016b. Anticonvulsant and procognitive properties of the non-imidazole histamine H3 receptor antagonist DL77 in male adult rats. Neuropharmacology.106, 46-55.

Sanchez-Borzone M, Delgado-Marín L, García DA. (2014) Inhibitory effects of carvone isomers on the GABAA receptor in primary cultures of rat cortical neurons. Chirality. 26:368-372

Sands, S. B., Costa, A. C., Patrick, J. W., 1993. Barium permeability of neuronal nicotinic receptor alpha 7 expressed in Xenopus oocytes. Biophys. J. 65, 2614-2621.

Singhal SK, Zhang L, Morales M, Oz M. (2007) Antipsychotic clozapine inhibits the function of alpha7-nicotinic acetylcholine receptors. Neuropharmacology. 52:387-394.

Spivak, C. E., Lupica, C. R., Oz, M., 2007. The endocannabinoid anandamide inhibits the function of alpha4beta2 nicotinic acetylcholine receptors. Mol. Pharmacol. 72, 1024-1032.

Szczot M, Czyzewska MM, Appendino G, Mozrzymas JW. (2012) Modulation of GABAergic synaptic currents and current responses by $\alpha$-thujone and dihydroumbellulone. J Nat Prod. 75:622-629.

Uteshev, V. V., 2012. alpha7 nicotinic ACh receptors as a ligand-gated source of $\mathrm{Ca}(2+)$ ions: the search for a $\mathrm{Ca}(2+)$ optimum. Adv. Exp. Med. Biol. 740, 603-638. 
Waidyanatha, S., Johnson, J.D., Hong, S.P., Robinson, V.G., Gibbs, S., Graves, S.W., Hooth, M.J., Smith, C.S., 2013. Toxicokinetics of $\alpha$-thujone following intravenous and gavage administration of $\alpha$-thujone or $\alpha$ - and $\beta$-thujone mixture in male and female F344/N rats and B6C3F1 mice. Toxicol. Appl. Pharmacol. 271, 216-228.

Welsby, P., Rowan, M., Anwyl, R., 2006. Nicotinic receptor-mediated enhancement of long-term potentiation involves activation of metabotropic glutamate receptors and ryanodine-sensitive calcium stores in the dentate gyrus. Eur. J. Neurosci.. 24, 3109-3118.

Welsby, P.J., Rowan, M.J., Anwyl, R., 2007 Beta-amyloid blocks high frequency stimulation induced LTP but not nicotine enhanced LTP. Neuropharmacology. 53,188-195.

Zhang, L., Oz, M., Stewart, R.R., Peoples, R.W., Weight, F.F., 1997. Volatile general anaesthetic actions on recombinant nACh $\alpha$, 5-HT3 and chimeric nACh $\alpha 7-5-\mathrm{HT} 3$ receptors expressed in Xenopus oocytes Br. J. Pharmacol. 120, 353-355 
ACCEPTED MANUSCRIPT

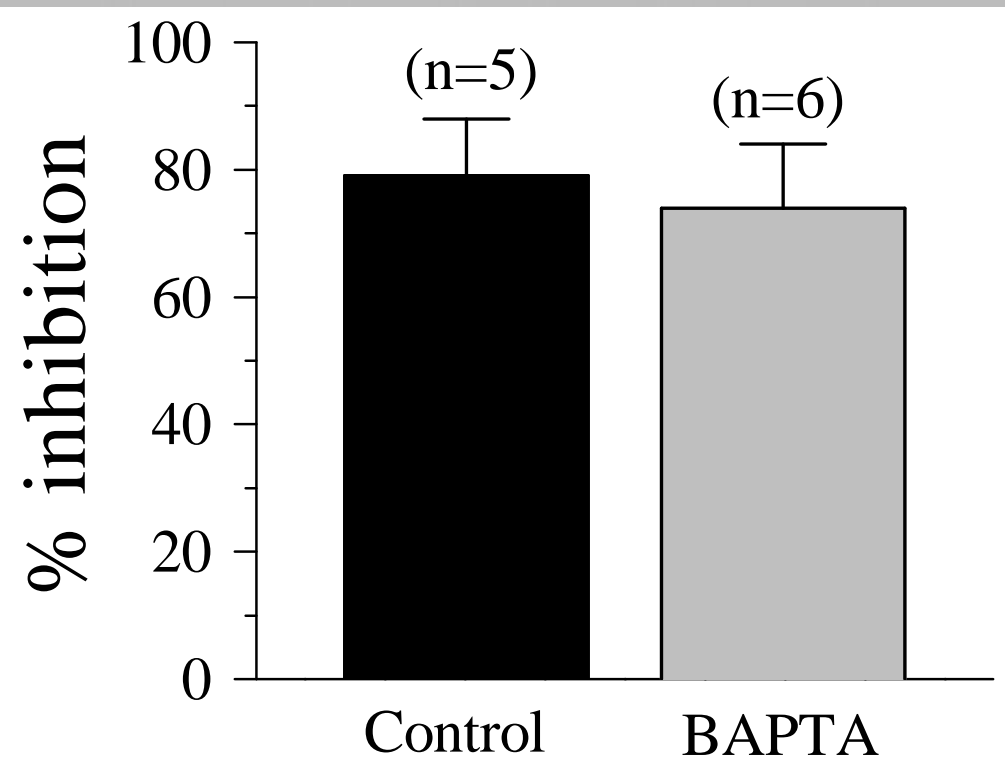

Figure 2

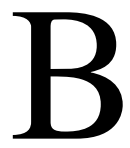

voltage $(\mathrm{mV})$
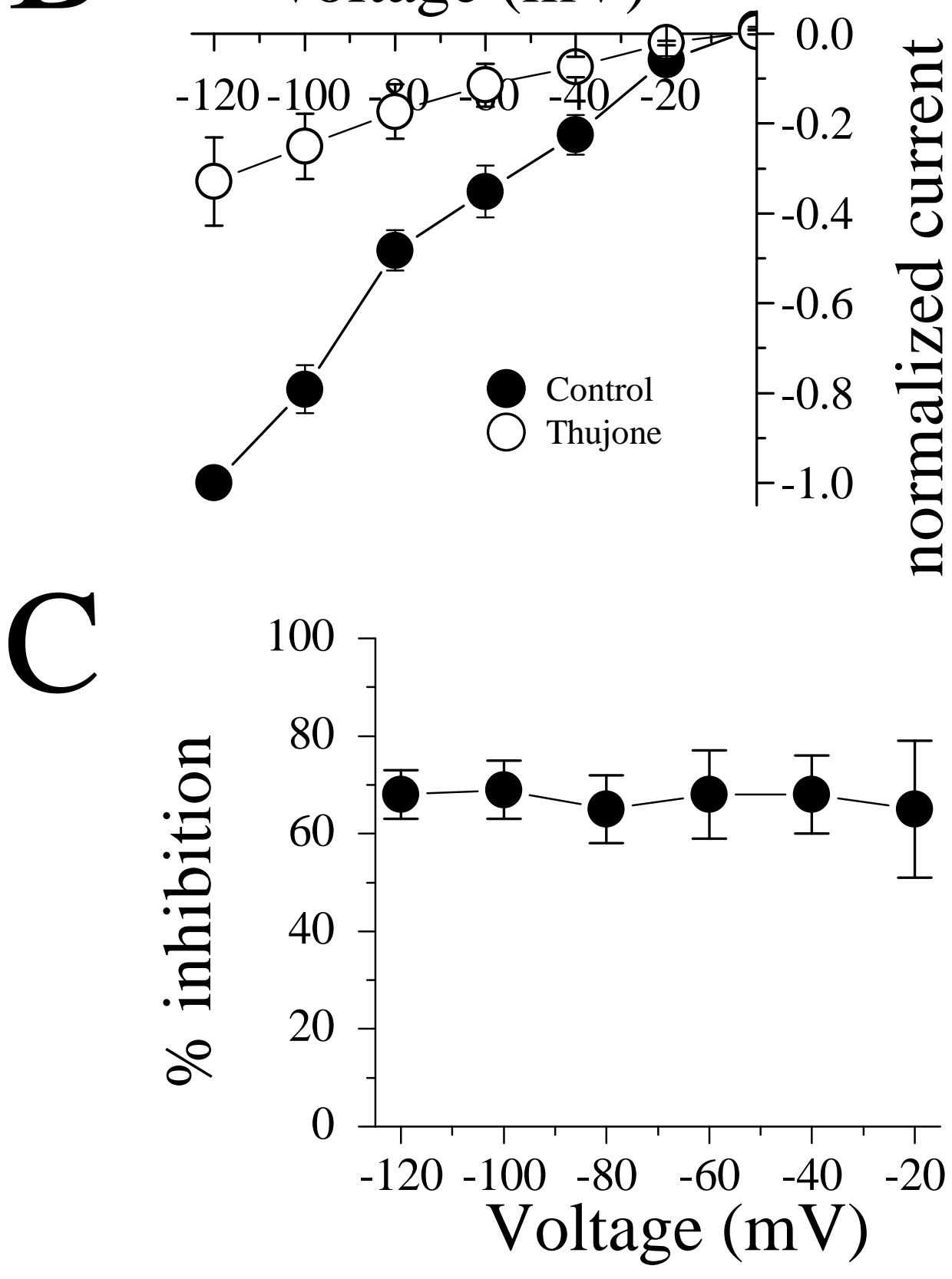
A
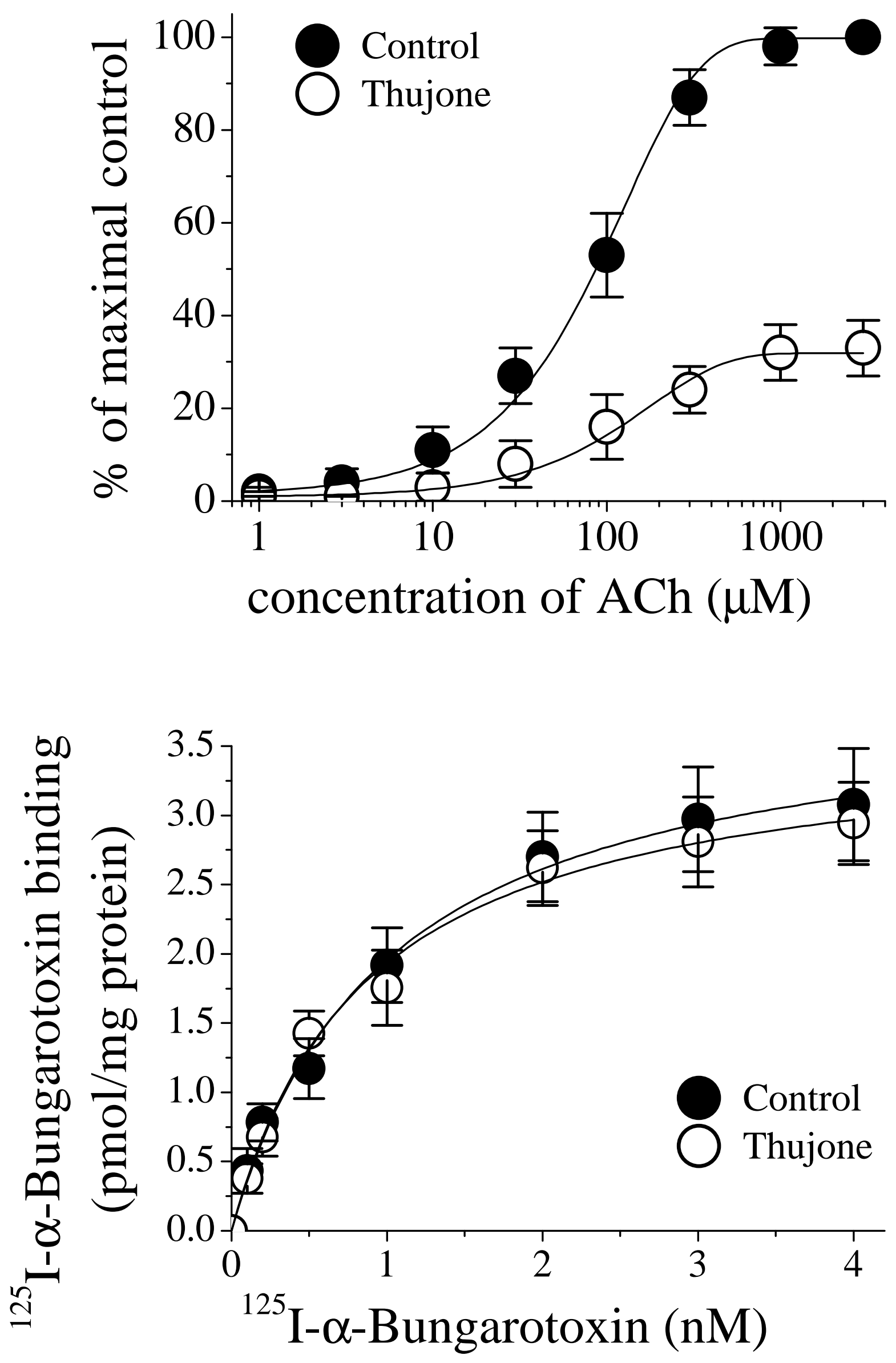
A

Nicotine

Control

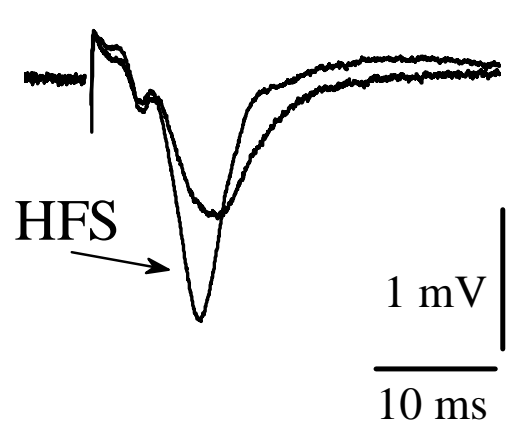

Nicotine

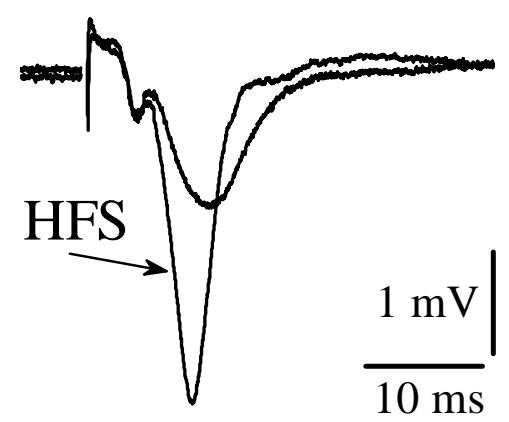

$+$

Thujone

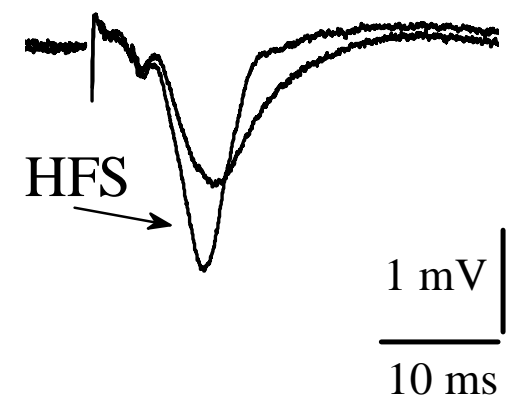

-o-Control

-- Nicotine

-4-Nicotine+Thujone

B

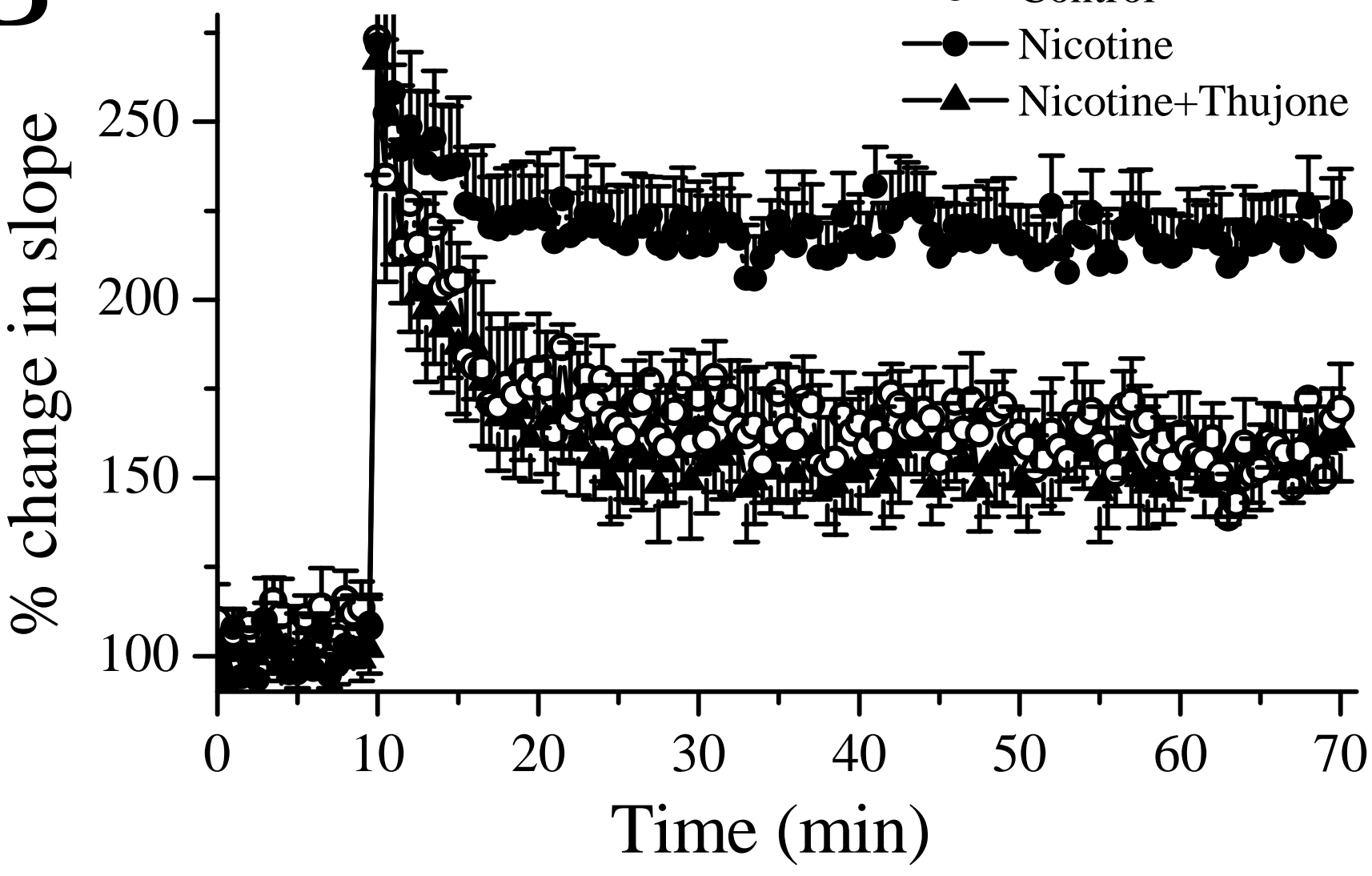



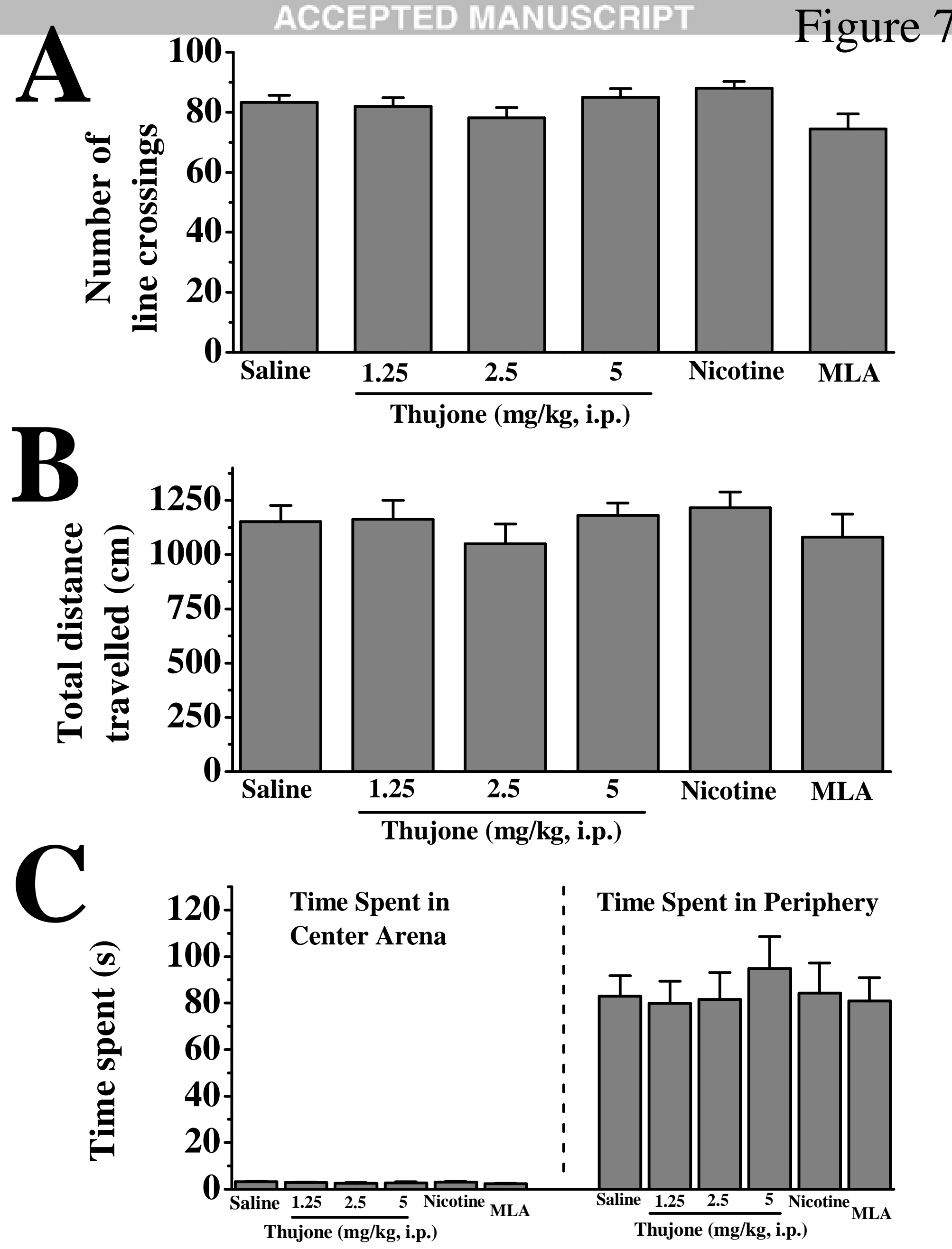